\title{
Mulching strategy provides higher healthier, and cleaner tomato (Solanum lycopersicum) crop in a profitable way
}

\author{
Hamed, Hend A. ${ }^{1}{ }^{*}$, H.A.O. Ali ${ }^{1}$, A.A. Said ${ }^{2}$ and K.A.A. El-Shaikh ${ }^{1}$ \\ ${ }^{1}$ Department of Horticulture, Faculty of Agriculture, Sohag University, 82524 Sohag, Egypt. \\ ${ }^{2}$ Department of Agronomy, Faculty of Agriculture, Sohag University, 82524 Sohag, Egypt.
}

\begin{abstract}
To manage natural resources and achieve agricultural sustainability, effective production strategies are required. For a healthier crop and a cleaner environment, reducing or eliminating chemical use is also a desirable goal. The goal of this study was to see how soil polyethylene mulch affected tomato crop output and quality. The Experimental Farm of the Faculty of Agriculture, Sohag University, Egypt, was used for two consecutive early summer seasons production. Manual weeding was used as a positive control treatment to compare its effect with black plastic mulch and herbicide on the growth, yield, and quality of two tomato hybrids (G.S-12 and Fayrouz). Weed density and biomass and economic profitability levels were also investigated. The use of black plastic mulch greatly enhanced all of the measured characteristics in both seasons, according to the data. i.e., vegetative traits, vitamin $\mathrm{C}$ content, total soluble solids, and N, P, and K leaves' concentrations. Data also revealed a superiority of G.S-12 hybrid over Fayrouz hybrid in most characters. Results showed a surprising effect for black plastic mulch treatment on smothering weed emergence compared with the conventional manual or chemical weed control treatments during the two seasons of considering. The hand-hoeing treatment proved to be the least viable weed control system among all treatments. This study recommends applying black plastic soil mulch in tomato production particularly in reclaimed soil conditions to reduce labor requirements and produce a higher, healthier output. In terms of gross margin and benefit-cost ratio (BCR) analyses, it also showed to be the optimum strategy.
\end{abstract}

Keywords: Profitability; Reclaimed soil; Soil polyethylene mulch; Sustainability; Weed control.

\section{Introduction}

Plasticulture refers to any thermoplastic application, including mulching systems (Yusak et al., 2016), that has become a widely used method in horticultural production around the world (Steinmetz et al., 2016). Increased and earlier yields, better soil structure, decreased fertilizer leaching, reduced soil competition via weed suppression (Hayes et al., 2019), and soilborne disease control are all advantages of using non-organic mulches on the soil surface.

\footnotetext{
*Corresponding author: Hend A. Hamed, Email:drhendhorti2017@gmail.com Received: September 11, 2021; Accepted: January 4, 2022; Published online: January 6, 2022. (C) Published by South Valley University. This is an open access article licensed under (c)(D)
}

The appeal of polyethylene (PE) mulch film stems from its ease of use, smoothness, and great durability, as well as the fact that it is odorless (He et al., 2016). It comes in a variety of colors and has a variety of effects (Decoteau, 2008). Plastic mulches in black and white are the most often used in the production of fresh vegetables around the world (Rajablariani et al., 2012). Despite clear PE mulch was used more common in hotter climates, this type of mulch often allowed weeds to grow beneath it (Decoteau, 2008; Shrefler and Brandenberger, 2014). Various authors, on the other hand, have described black mulch as an alternative to traditional manual or chemical weed management approaches (Hayes et al., 2019). 
The high light transmission increased soil temperature and created a microclimate conducive to weed germination (Rajablariani et al., 2015).

Tomato (Solanum lycopersicum), a solanaceous crop, is the most important horticultural crop in the world (Schwarz et al., 2014; Bhandari et al., 2017), and ranks first among all vegetable crops farmed in Egypt (El-Wahed et al., 2020). It is well adapted to its soil and climate conditions and grown all year round (Shamshiri et al., 2018). Vegetable cultivation in the open field during the early summer and summer seasons has numerous challenges, including significant weed infestation (Kumar et al., 2016) and intense competition for limited water with other summer crops. This has resulted in a significant decrease in both yield and quality. Furthermore, weed competition in tomato production is seen as a key stumbling block for farmers who want to switch to organic farming (Rajablariani et al., 2015).

Despite several reports of the favorable effects of utilizing plastic mulches, their use by farm smallholders in Egypt is still quite limited, and we sought to diversify our use of such strategies to boost vegetable yield and farmers' revenue. The current approach objectively assessed how tomato hybrids responded to the application of black plastic mulch on tomato productivity and quality in reclaimed soil conditions.

\section{Materials and methods}

This research paper presents the results of two years of studies at the Experimental Farm of Fac. of Agri., Sohag Univ., Egypt where the soil is sandy loam (47.56 sand, 39.00 silt, and 13.44 clay). In the experiment, two tomato hybrids were used; G.S-12 and Fayrouz. In both years, tomato transplanting was done in the $1^{\text {st }}$ week of February (early summer season).

Before transplanting, a black plastic mulch (90 $\mathrm{cm}$ width, $50 \mathrm{~m}$ thickness) was laid out on the soil surface, and transplants were placed in small

holes drilled in the plastic film (Fig. 1). At 40 days after transplanting, metribuzin (Vapcor 70 percent) post-emergence herbicide (4-amino-6(1,1-dimethylethyl)-3-methylthio)-1,2, 4-triazin$5(4 \mathrm{H})$-one was sprayed at a rate of $(10 \mathrm{~g} / 20$ litre water). Hand hoeing was done three times at (3, 6 , and 9 weeks from transplanting). The plot size was kept at $3 \mathrm{~m} \mathrm{x} 3.5 \mathrm{~m}\left(10.5 \mathrm{~m}^{2}\right)$, the line width was $80 \mathrm{~cm}$, seedlings were transplanted in one side of the rows, and $30 \mathrm{~cm}$ apart within-row. For tomato production, all prescribed agricultural techniques were followed.

\subsection{Experimental Design}

A split-plot design with eight treatments (4 treatments along with 2 tomato hybrids) has been applied. The two tomato hybrids served as the main plots, with the four treatments scattered at random as subplots. The following treatments were carried out: 1-A negative control was an un-weeded treatment, 2- while a positive control was hand hoeing. 3- Mulching the soil surface with black plastic mulch. 4-Applying postemergence herbicide (Metribuzin). The experiment was set up in four replicates.

\subsection{Measurements}

\subsubsection{Vegetative parameters}

The main stem height $(\mathrm{cm})$, number of branches, fruit set percentage (\%), average fruit weight $(\mathrm{g})$, early fruit yield (tonne/acre), and total fruit yield (tonne/acre.) were all recorded for the yield and its components.

\subsubsection{Chemical composition}

Tomato fruit quality characteristics; ascorbic acid content $(\mathrm{mg} / 100 \mathrm{~g})$ and total soluble solids (TSS percent) were determined according to (A.O.A.C. 2016). In addition, the contents of nitrogen $(\mathrm{N})$, phosphorus $(\mathrm{P})$, and potassium $(\mathrm{K})$ in tomato leaves were determined using Metcalfe (1987) and George et al. (2013) methods.

\subsubsection{Weed density and weed biomass}


Following the method of Rajablariani et al. (2012), the number and weight of both narrowleaf weeds and broad-leaf weeds were separately determined, 70 days after tomato transplanting (Fig.1).

according to Rahman et al. (2006), benefit-Cost Ratio analysis (BCR) was calculated to show the economic efficiency.

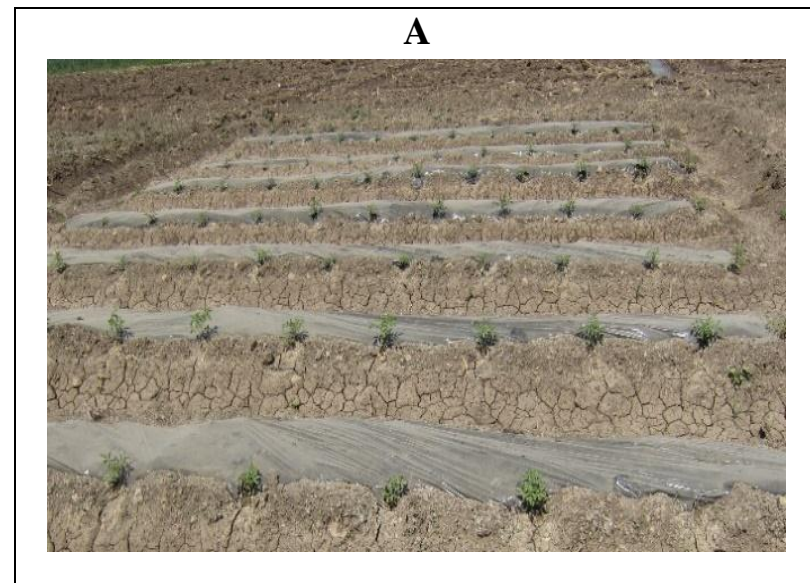

Fig 1. A. Transplanting in the mulched plots.

\section{Results}

\subsection{Tomato yield and its components}

Statistical analysis showed significant values for all agronomic parameters tested in the two years of the study (Tables (1, 2, and 3) and Fig. (2)). In terms of the effect of the two tomato hybrids, our findings revealed that in both seasons, the agronomic properties of G.S-12 and Fayrouz hybrids were significantly different. The higher values were achieved by G.S-12 hybrid in vegetative growth, fruit set percentage, early, and total yield (tonne/acre). i.e., GS produced plants taller by (10.12 and 10.72) \% than Fayrouz in the $1^{\text {st }}$ and $2^{\text {nd }}$ seasons, respectively.

In both seasons, black plastic mulch significantly enhanced tomato plant height, number of branches, fruit set percentage, early and total yields when compared to the other

\subsection{Statistical analysis}

All data were subjected to analysis of variance (Gomez and Gomez, 1984), and means were compared at the 0.05 probability level using "The Least Significant Difference" (LSD) Test.

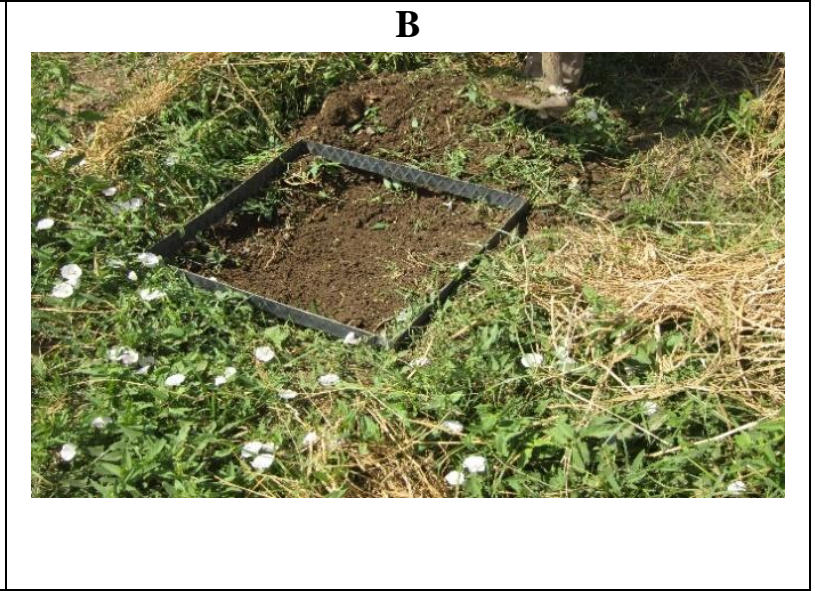

B. Using the meter square for collecting weeds.

treatments. in the first and second seasons, black PE had the greatest fruit set percentages (54.63 and57.90, respectively).

the highest early yield values were obtained by using black PE (7.12 and 9.55) tonne/acre, followed by using herbicide treatment (5.79 and 5.59) tonne/acre in the first and second seasons, respectively. the highest total yield was obtained by using black plastic mulch (23.23 and 27.67) tonne/acre, followed by using metribuzin herbicide (18.68 and 17.12) tonne/acre in the $1^{\text {st }}$ and $2^{\text {nd }}$ seasons, respectively. As compared to control, using plastic mulch increased total yield by $(63.1 \%$ and $75.6 \%)$ in the $1^{\text {st }}$ and $2^{\text {nd }}$ seasons, respectively.

In the two experiments, the optimum combination of agronomical qualities was polyethylene mulch PE treatment and G.S-12 tomato hybrid. 
Table 1. The main stem height and number of branches of two tomato hybrids as affected by black plastic mulch, herbicide, and hand-hoeing during the two seasons under reclaimed soil conditions.

\begin{tabular}{|c|c|c|c|c|c|c|}
\hline \multirow{4}{*}{$\begin{array}{l}\text { Season } \\
\text { Treatment }(\mathrm{T})\end{array}$} & \multicolumn{5}{|c|}{ Main stem height $(\mathrm{cm})$} & \multirow{4}{*}{ Mean } \\
\hline & \multicolumn{2}{|c|}{ Season (1) } & \multicolumn{3}{|c|}{ Season (2) } & \\
\hline & \multicolumn{2}{|c|}{ Tomato hybrid $(\mathrm{H})$} & \multirow[t]{2}{*}{ Mean } & \multicolumn{2}{|c|}{ Tomato hybrid $(\mathrm{H})$} & \\
\hline & GS-12 & Fayrouz & & GS-12 & Fayrouz & \\
\hline Black mulch & 63.75 & 52.25 & 58.00 & 66.25 & 64.75 & 65.50 \\
\hline Herbicide & 59.50 & 48.50 & 54.00 & 57.50 & 51.50 & 54.50 \\
\hline Hand-hoeing & 50.25 & 52.25 & 51.25 & 63.50 & 48.75 & 56.13 \\
\hline Control & 48.00 & 46.00 & 47.00 & 50.75 & 47.50 & 49.13 \\
\hline Mean & 55.88 & 49.25 & & 59.51 & 53.13 & \\
\hline L.S.D 0.05 & $\mathrm{~T}: 3.77$ & H: 1.79 & HT: 5.34 & $\mathrm{~T}: 4.63$ & $\mathrm{H}: 2.69$ & HT: 6.55 \\
\hline \multicolumn{7}{|c|}{ Number of branches } \\
\hline \multirow{4}{*}{$\begin{array}{l}\text { Season } \\
\text { Treatment (T) }\end{array}$} & \multirow{2}{*}{\multicolumn{2}{|c|}{ Season (1) }} & \multicolumn{4}{|c|}{ Season (2) } \\
\hline & & & \multirow{3}{*}{ Mean } & & & \\
\hline & \multicolumn{2}{|c|}{ Tomato hybrid $(\mathrm{H})$} & & \multicolumn{2}{|c|}{ Tomato hybrid (H) } & Mean \\
\hline & GS-12 & Fayrouz & & GS-12 & Fayrouz & \\
\hline Black mulch & 7.50 & 7.00 & 7.25 & 8.00 & 7.50 & 7.75 \\
\hline Herbicide & 6.75 & 5.85 & 6.30 & 7.00 & 6.50 & 6.75 \\
\hline Hand-hoeing & 6.00 & 5.25 & 5.63 & 6.75 & 5.75 & 6.25 \\
\hline Control & 5.00 & 4.25 & 4.63 & 5.00 & 4.00 & 4.50 \\
\hline Mean & 6.31 & 5.59 & & 6.70 & 5.94 & \\
\hline L.S.D ${ }_{0.05}$ & $\mathrm{~T}: 0.89$ & $\mathrm{H}: 0.51$ & HT: 1.27 & $\mathrm{~T}: 0.96$ & H: 0.68 & HT: 1.36 \\
\hline
\end{tabular}

T: treatment; H: Hybrid; HT: Hybrid*Treatment

Table 2. The early and total yield of two tomato hybrids as affected by black plastic mulch, herbicide, and hand- hoeing during the two seasons under reclaimed soil conditions.

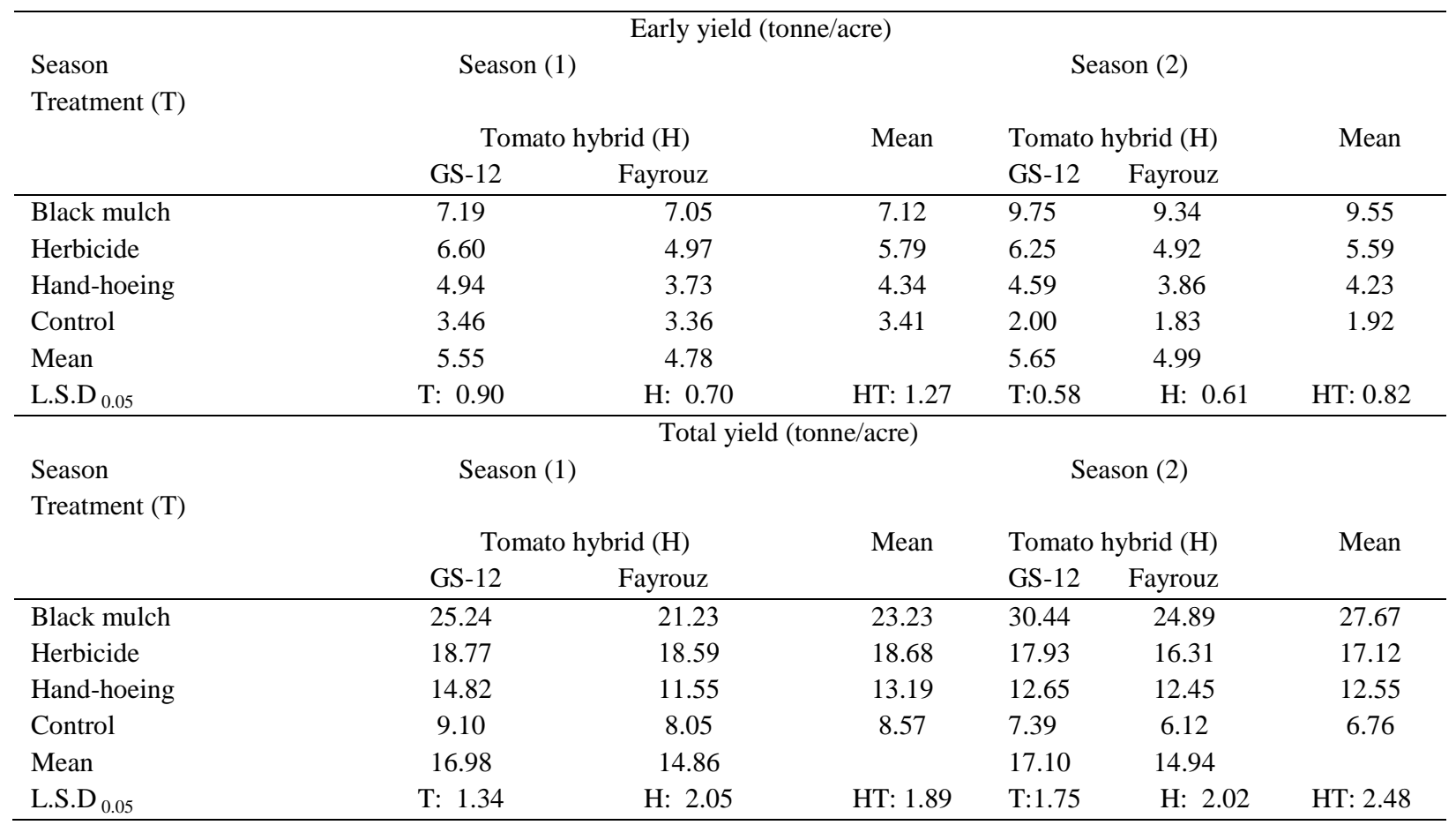

T: treatment; H: Hybrid; HT: Hybrid*Treatment 
Table 3. Fruit set percentage (\%) of two tomato hybrids as affected by black plastic mulch, herbicide , and hand-hoeing during the two seasons under reclaimed soil conditions.

\begin{tabular}{|c|c|c|c|c|c|c|}
\hline \multirow{4}{*}{$\begin{array}{l}\text { Seasons } \\
\text { Treatment }(\mathrm{T})\end{array}$} & \multicolumn{3}{|c|}{ Fruit set percentage (\%) } & \multirow{2}{*}{\multicolumn{2}{|c|}{$2^{\text {nd }}$ season }} & \multirow{4}{*}{ Mean } \\
\hline & \multicolumn{2}{|c|}{$1^{\text {st }}$ season } & \multirow{3}{*}{ Mean } & & & \\
\hline & \multicolumn{2}{|c|}{ Tomato hybrid $(\mathrm{H})$} & & \multicolumn{2}{|c|}{ Tomato hybrid (H) } & \\
\hline & GS-12 & Fayrouz & & GS-12 & Fayrouz & \\
\hline Black mulch & 60.25 & 49.00 & 54.63 & 62.95 & 52.85 & 57.90 \\
\hline Herbicide & 48.00 & 40.75 & 44.38 & 54.4 & 48.52 & 51.50 \\
\hline Hand-hoeing & 39.25 & 38.75 & 39.00 & 52.65 & 51.20 & 51.93 \\
\hline Control & 34.62 & 29.35 & 31.99 & 35.70 & 34.00 & 34.85 \\
\hline Mean & 45.53 & 39.46 & & 51.44 & 46.64 & \\
\hline L.S.D ${ }_{0.05}$ & $\mathrm{~T}: 3.08$ & H:5.60 & HT: 4.36 & $\mathrm{~T}: 4.21$ & $\mathrm{H}: 1.47$ & HT: 5.96 \\
\hline
\end{tabular}

T: treatment; H: Hybrid; HT: Hybrid*Treatment.

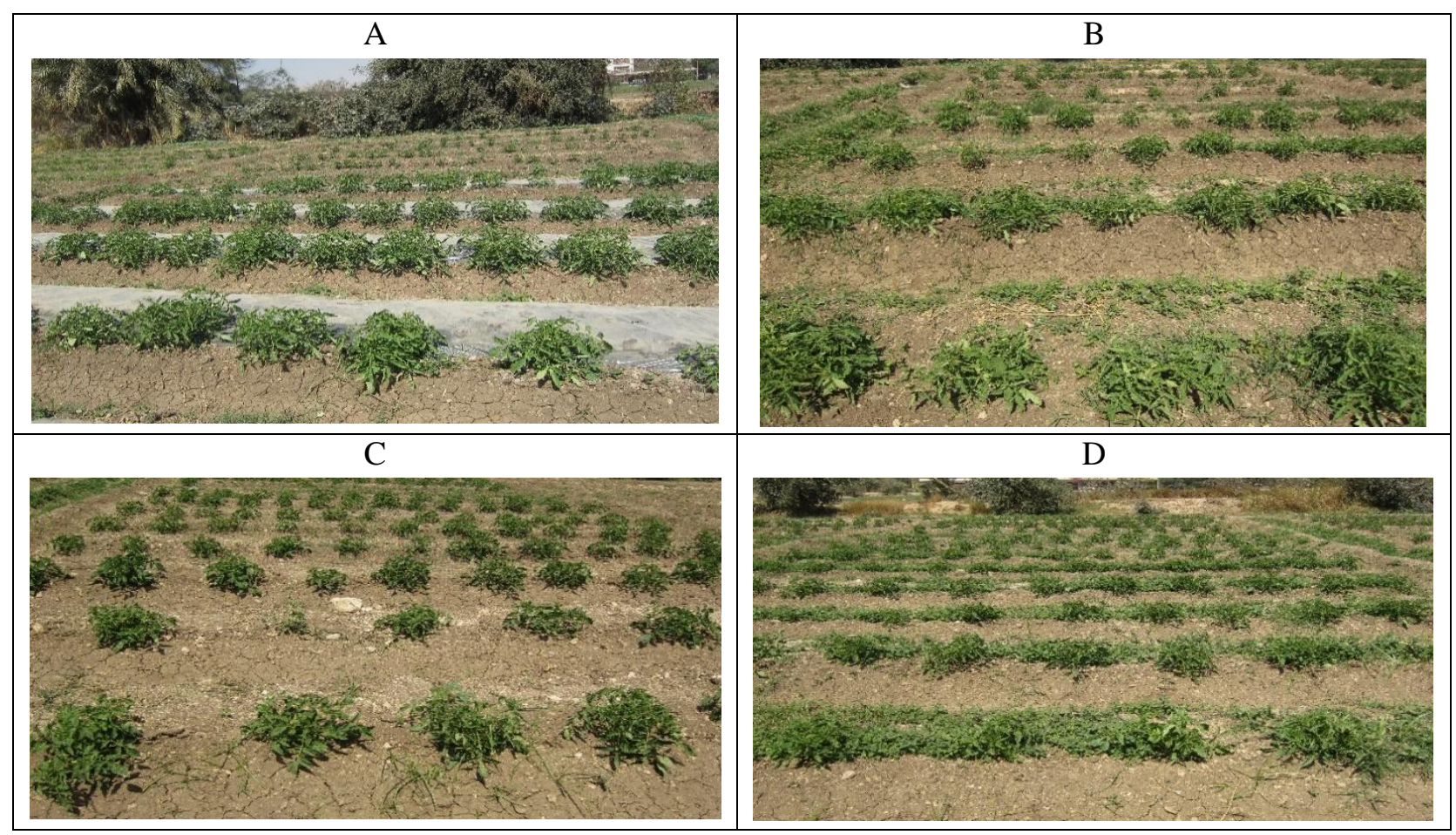

Fig 2. vegetative growth in the 4 treatments; A: plastic mulch treatment, B: herbicide treatment, C: manual weeding treatment, D: un-weeded treatment (control).

\subsection{Chemical composition}

The chemical analyses included the tomato fruits' ascorbic acid and total soluble solids content Table (4) as well as tomato leaves' macro elements $\mathrm{N}, \mathrm{P}$, and $\mathrm{K}$ concentrations Fig. $(3,4$, and 5$)$.

\subsubsection{Tomato fruits' quality parameters}

Table (4) shows that the Fayrouz tomato hybrid outperformed the G.S-12 tomato hybrid in terms of vitamin $(\mathrm{C})$ content.

All treatments affected the ascorbic acid concentration of tomato fruits as compared to the control. The application of black plastic 
mulch treatment resulted in the highest vitamin $\mathrm{C}$ content $(12.83$ and $12.78 \mathrm{mg} / 100 \mathrm{~g}$ ) in the first and second seasons, respectively, as well as the highest TSS levels (4.49 and 4.58 percent).
However, no significant difference was found between using herbicide and hand hoeing treatments regarding the two quality parameters tested.

Table 4. Means of ascorbic acid content (mg/100g), and total soluble solids (\%) of two tomato hybrids as affected by black plastic mulch, herbicide, and hand- hoeing during the two seasons under reclaimed soil conditions.

\begin{tabular}{|c|c|c|c|c|c|c|}
\hline \multirow{4}{*}{$\begin{array}{l}\text { Season } \\
\text { Treatment }(\mathrm{T})\end{array}$} & \multicolumn{5}{|c|}{ Ascorbic acid content (mg/100g) } & \multirow{4}{*}{ Mean } \\
\hline & \multicolumn{2}{|c|}{ Season (1) } & \multicolumn{3}{|c|}{ Season (2) } & \\
\hline & \multicolumn{2}{|c|}{ Tomato hybrid $(\mathrm{H})$} & \multirow[t]{2}{*}{ Mean } & \multicolumn{2}{|c|}{ Tomato hybrid $(\mathrm{H})$} & \\
\hline & GS-12 & Fayrouz & & GS-12 & Fayrouz & \\
\hline Black mulch & 11.90 & 13.75 & 12.83 & 12.25 & 13.30 & 12.78 \\
\hline Herbicide & 8.82 & 9.57 & 9.20 & 8.93 & 8.96 & 8.95 \\
\hline Hand-hoeing & 8.05 & 10.20 & 9.13 & 8.72 & 9.62 & 9.17 \\
\hline Control & 6.87 & 7.95 & 7.41 & 7.15 & 10.05 & 8.60 \\
\hline Mean & 8.91 & 10.37 & & 9.26 & 10.48 & \\
\hline \multirow[t]{2}{*}{ L.S.D 0.05} & $\mathrm{~T}: 1.06$ & $\mathrm{H}: 1.21$ & HT: 1.59 & $\mathrm{~T}: 0.35$ & H:0.62 & HT:0.50 \\
\hline & \multicolumn{5}{|c|}{ Total soluble solids (\%) } & \\
\hline \multirow{3}{*}{$\begin{array}{l}\text { Season } \\
\text { Treatment }(\mathrm{T})\end{array}$} & \multicolumn{2}{|c|}{ Season (1) } & & \multicolumn{2}{|c|}{ Season (2) } & \\
\hline & \multicolumn{2}{|c|}{ Tomato hybrid $(\mathrm{H})$} & Mean & \multicolumn{2}{|c|}{ Tomato hybrid $(\mathrm{H})$} & Mean \\
\hline & GS-12 & Fayrouz & & GS-12 & Fayrouz & \\
\hline Black mulch & 4.30 & 4.67 & 4.49 & 4.50 & 4.65 & 4.58 \\
\hline Herbicide & 3.80 & 4.00 & 3.90 & 4.10 & 3.87 & 3.99 \\
\hline Hand-hoeing & 3.92 & 3.80 & 3.86 & 3.75 & 4.15 & 3.95 \\
\hline Control & 3.43 & 3.63 & 3.53 & 3.63 & 3.81 & 3.72 \\
\hline Mean & 3.86 & 4.03 & & 3.99 & 4.12 & \\
\hline L.S.D 0.05 & $\mathrm{~T}: 0.33$ & H: NS & HT: 0.46 & $\mathrm{~T}: 0.22$ & $\mathrm{H}: \mathrm{NS}$ & HT: 0.31 \\
\hline
\end{tabular}

T: treatment; H: Hybrid; HT: Hybrid*Treatment.

\subsubsection{Tomato leaves' macro-elements}

Results in Fig. (3,4, and 5) concerning the concentration of the nutrients in the leaves of two tomato hybrids tested showed that G.S-12 hybrid was significantly higher in $\mathrm{N}$, and $\mathrm{K}$ concentrations compared to Fayrouz hybrid. Meanwhile, no significant difference was found in $\mathrm{P}$ concentration in both years.
During the two experimental seasons, all of the tested treatments surpassed the control treatment. The use of polyethylene mulch PE gave significantly higher concentrations of $\mathrm{N}, \mathrm{P}$, and $\mathrm{K}$ nutrients compared to all other treatments. On the other hand, the highest values were obtained from the combination between G.S-12 hybrid and black mulch treatment in both years of the study. 


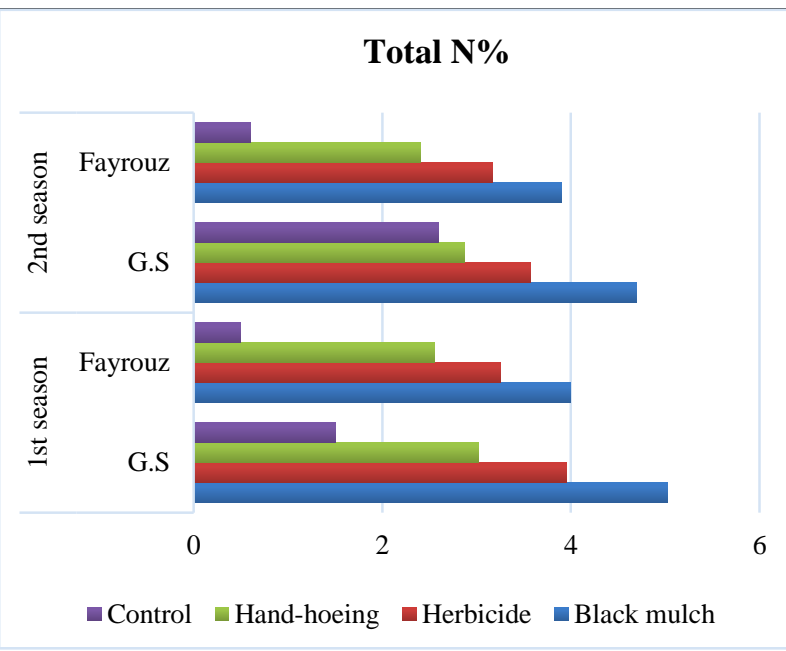

Fig 3. Means of N percentage of two tomato hybrids as affected by black plastic mulch, herbicide, and hand-hoeing.

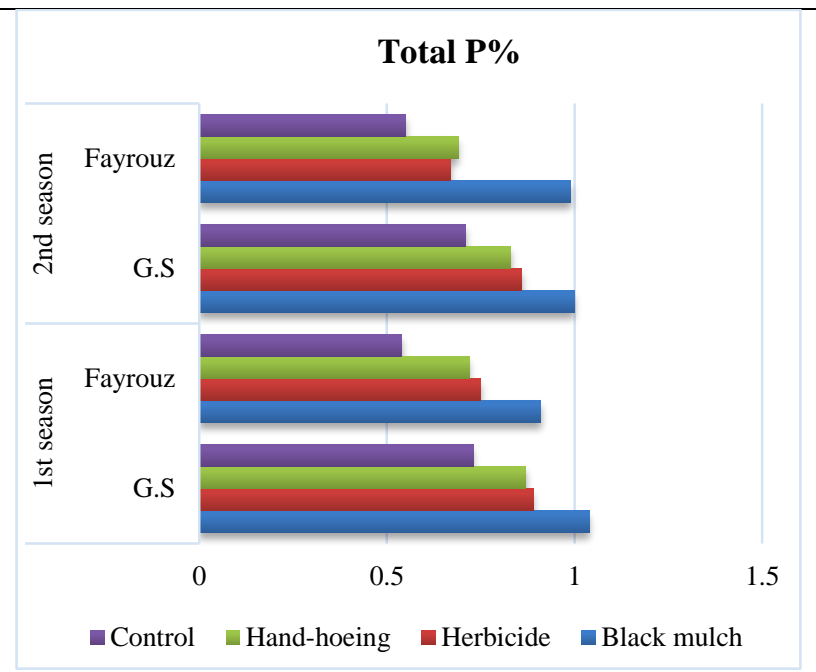

Fig 4. Means of $P$ percentage of two tomato hybrids as affected by black plastic mulch, herbicide, and hand-hoeing.

\section{Total K\%}

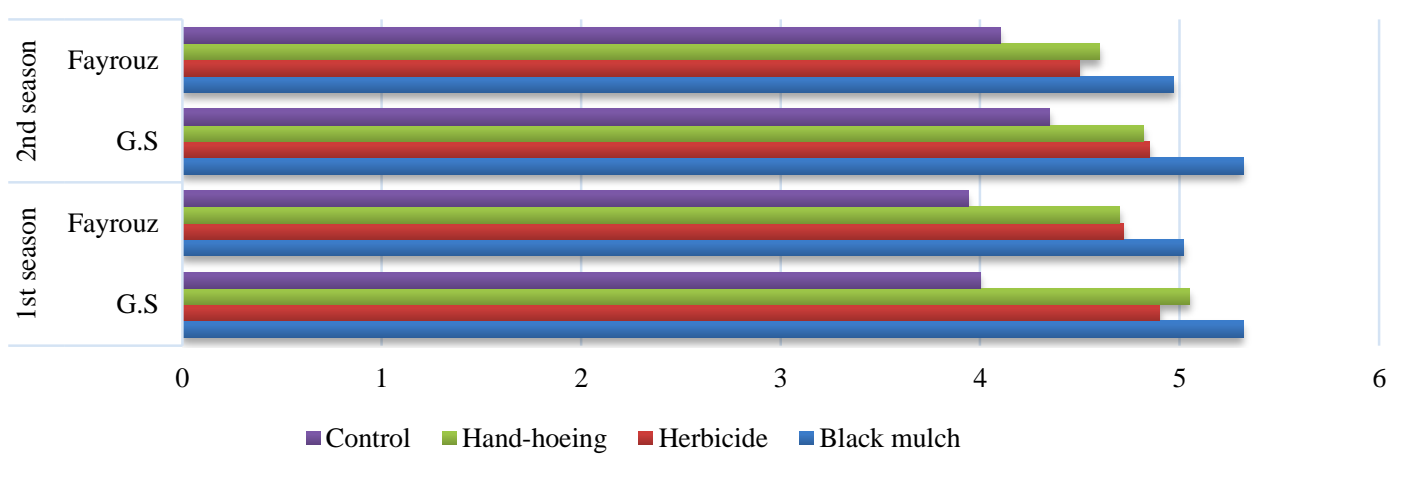

Fig 5. Means of K percentage of two tomato hybrids as affected by black plastic mulch, herbicide, and hand-hoeing.

\subsection{Weed density and biomass}

It is shown in Table (6) that the weeds collected were; (Cyperus rotundus, Nerium oleander, Cynodon dactylon) as narrow leaf-weeds, and (Chenopodium ambrosioides, Malva parviflora, Portulaca oleraceae, Convolvulus arvensis, Rumex vesicarius, Rumex dentatus, Sonchus oleraceus) as broad-leaf weeds.

Results concerning the number of both narrow and broad-leaf weeds, as well as their fresh and dry weights, are illustrated in Fig. (6,7,8 and 9). Data obviously revealed that no significant differences were observed between hybrids in either weeds number or the fresh and dry weights in the two experimental seasons. However, considerable influences were detected owing to all studied treatments in this respect. data clearly showed that all treatments significantly affected the number of weeds $/ \mathrm{m}^{2}$ and the weeds infestation $\left(\mathrm{g} / \mathrm{m}^{2}\right)$ compared to the control. The highest weed density and coverage values were observed in the un-weeded plot (control) i.e. $(1457.85,1542.34) \mathrm{g} / \mathrm{m}^{2}$, and $(284.30,272.13) \mathrm{g} / \mathrm{m}^{2}$ for fresh and dry weight in the $1^{\text {st }}$ and $2^{\text {nd }}$ seasons, respectively. 
However, complete elimination of weeds was observed with the use of black plastic mulch which was one of our most interesting results.
Hand-hoeing treatment proved to be the lowest effective weed control system in this study as compared to mulching and herbicides in both seasons.

Table 5. All kinds of weeds found in the experimental area, and suppressed by plastic mulch.

\begin{tabular}{ll}
\hline Narrow-leaf weeds & Broad-leaf weeds \\
\hline Cyperus rotundus & Chenopodium ambrosioides \\
Nerium oleander & Malva parviflora \\
Cynodon dactylon & Portulaca oleraceae \\
& Convolvulus arvensis \\
& Rumex vesicarius \\
& Rumex dentatus \\
& Ammi visnaga \\
& Sonchus oleraceus $L$. \\
& \\
\end{tabular}

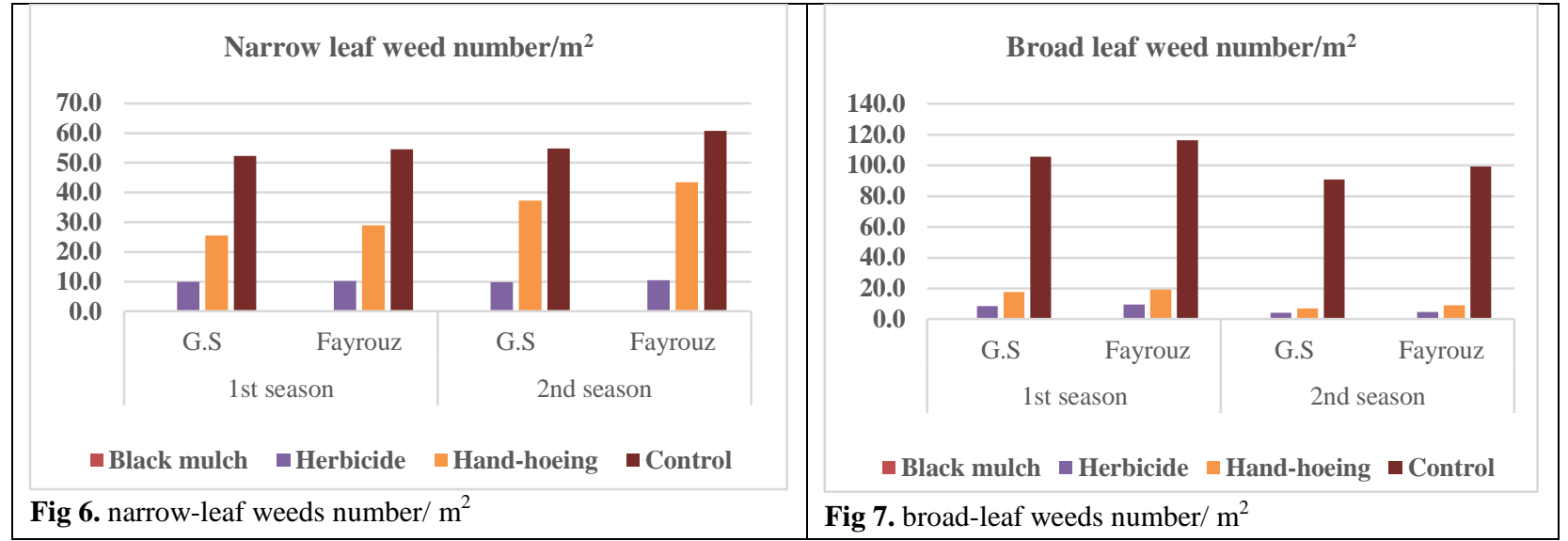

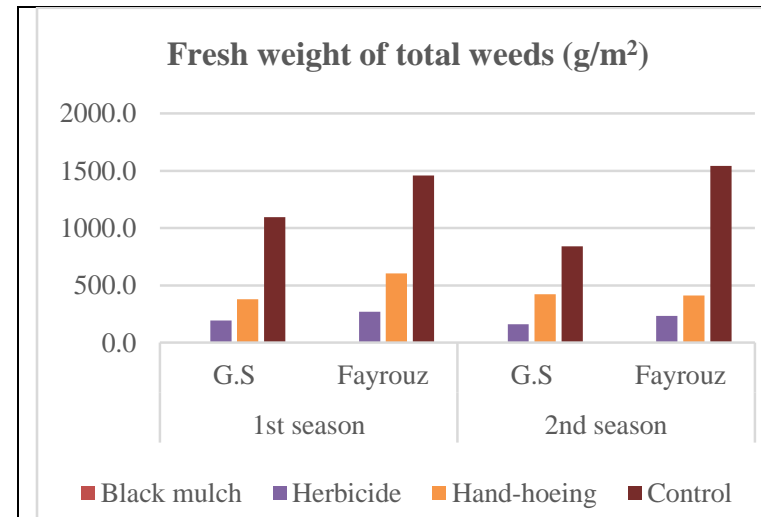

Fig 8. Fresh weight of total weeds $\left(\mathrm{g} / \mathrm{m}^{2}\right)$

\subsection{Benefit-cost ratio analysis}

All agricultural production systems have costs, which affect financial returns and the owner's decision to proceed or forego investments. Monitoring production costs and market prices
Dry weight of total weeds $\left(\mathrm{g} / \mathrm{m}^{2}\right)$

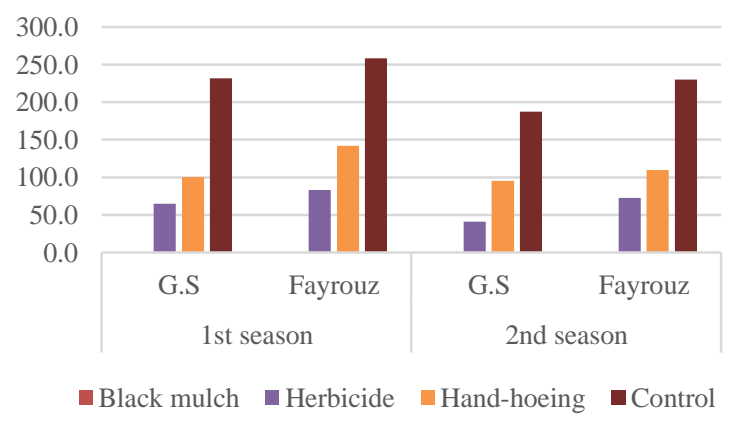

Fig 9. Fresh weight of total weeds $\left(\mathrm{g} / \mathrm{m}^{2}\right)$

are critical for using plastic mulch for tomato production. In this regard, the amount of control is usually balanced between the costs involved in control and the amount of possible negative effects on the crop. 
Our results given in Table (7) and Fig. (10) showed the economic profitability levels obtained from different treatments over two years. Data revealed that plastic mulch showed the highest gross returns in the early and total yields. Herbicide treatment occupied the second rank between treatments. It achieved gross returns i.e., $(23160,25155)$ and $(58608,54705)$ EGP in the early and total yields in the $1^{\text {st }}$ and $2^{\text {nd }}$ seasons, respectively. While control treatment occupied the last one related to the gross return.

Data also revealed that plastic mulch showed the highest total cost $(18219,20490)$ EGP in the $1^{\text {st }}$ and $2^{\text {nd }}$ seasons, respectively. While control treatment occupied the last one between treatments regarding the total cost. Results in the same Table also revealed that plastic mulch recorded the highest gross margin (54564, 67785) EGP in the $1^{\text {st }}$ and $2^{\text {nd }}$ seasons, respectively. Herbicide treatment occupied the second rank between treatments. While control treatment occupied the last one related to the gross margin.

The Benefit-Cost Ratio analysis has indicated that plastic mulch recorded the highest ratio in the two seasons which covered total cost by about (4 and 4.5) times in the first and second seasons, respectively, followed by herbicide treatment which covered total cost recording about (3.3 and 2.8) times in the first and second seasons, respectively. While control treatment occupied the last one between treatments regarding the benefit-cost ratio which recorded about (2.1 and 1.5) times compared to its total cost.

Table 6. Profitability levels of different treatments on the yield of tomato per feddan at the study site during the two seasons of study.

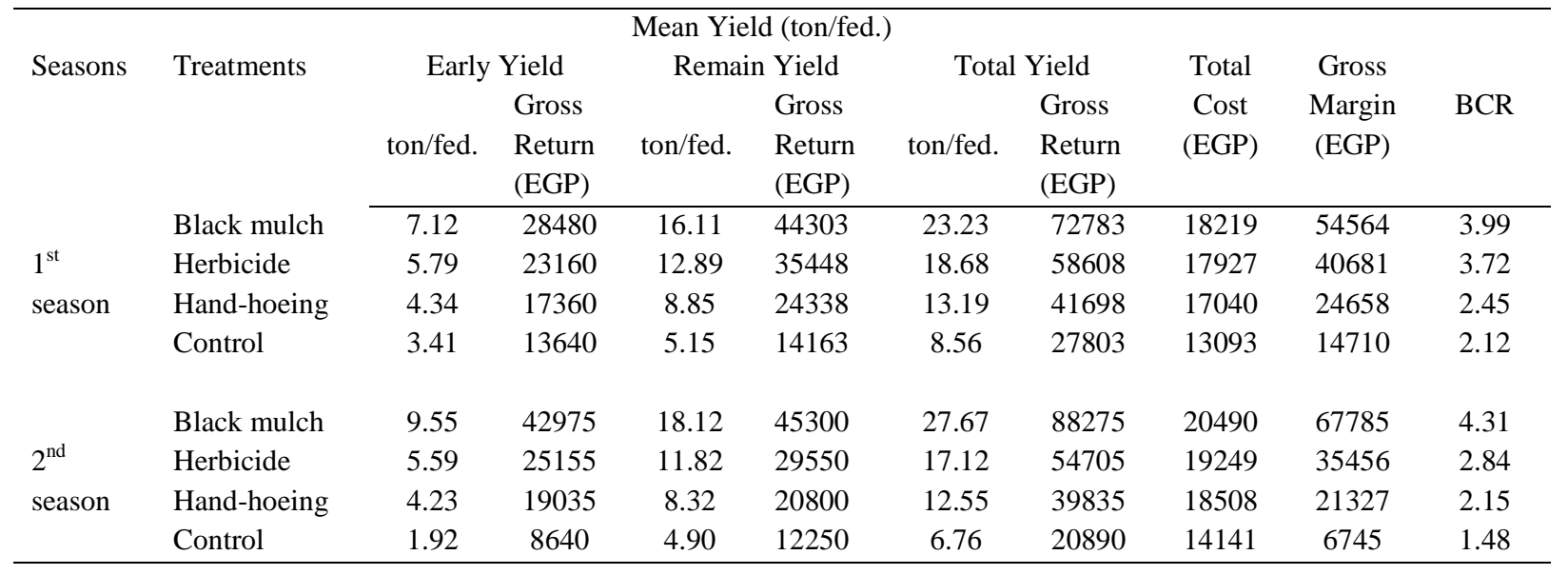

\section{Discussion}

Since agriculture is the main component in the Egyptians' economy, and food security is significantly limited by soil and water resources, there is a growing need to develop effective policies for the long-term management of natural resources (Doro et al., 2020). Summer vegetable crops' growth is threatened by many factors such as water scarcity (Abdelsamie et al.,
2012) and heavy weed infestation. Weeds have severe adverse effects on vegetable production. Yields frequently are reduced by their competing with vegetables for water, nutrients, and light as well as many harbors insect and disease organisms. (Welbaum, 2015; Alyokhin et al., 2020).

Weeds also pose a problem by reducing the efficiency of water distribution and drainage 
systems. Jayan and Sathyanathan (2012). Plastic film mulch technology can help to control the environmental conditions surrounding plants to provide a suitable climate and to maximize agricultural productivity (Lalitha et al., 2010; Patil et al., 2013; Sharma and Bhardwaj, 2017), nevertheless, it is not widely used in Egypt particularly among smallholders. We wanted to boost smallholder farm productivity and income while also improving regional agricultural production and maintaining food security in the current research study.

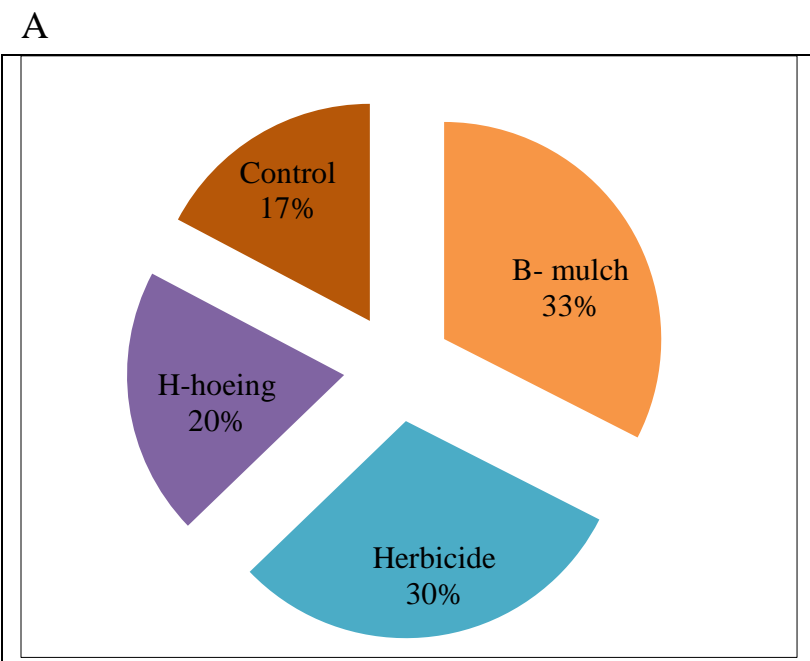

B

Fig 10. Benefit-cost ratio (BCR) analysis; A: BCR in the first year, B: BCR in the second year.

Fascinatingly, our results showed the complete elimination of weeds by applying black plastic mulch to the soil surface before tomato crop transplanting. We hypothesized that light transmission is a feature that may be more easily regulated in the development of a weed management approach, black mulch could inhibit weed germination. Similar findings were found by Hudu et al. (2002) and Johnson et al. (2005). Furthermore, according to Sintim and Flury (2017), the usage of polyethylene mulch can aid in the control of weeds and insects.

Our findings are also consistent with those of Tomar et al. (2020) who found that putting black mulch to the soil prevented light from passing through it, which is important for photosynthesis essentially required for the growth of weed plants. Soil mulching is also done before crop cultivation to reduce arable weeds and/or pathogenic microbes during the subsequent crop cultivation phase, according to Nishimura et al. (2012).
It is pertinent to note that, a greater potential for chemical control exists with the help of black mulch film. It is critical to reduce herbicide use while avoiding unwanted repercussions. Obviously, our research demonstrated that herbicide application was the second most effective weed control method after polyethylene mulch. These findings suggested that mulching could be a promising product for reducing pollution by reducing the accumulation of chemical residues in soil and plants. The rise in nitrogen, phosphorus, and potassium concentrations in tomato leaves grown in mulched plots, on the other hand, could be due to less weed infestation, allowing for higher nutrient uptake in the rhizosphere, which reflects plant health and is directly related to output. Reducing water loss, warming soil could be other factors to enhance nutrient uptake.

According to Rashidi et al. (2010), changes in the micro-environment caused by soil mulch compared to bare ground include changes in root-zone temperature as well as the quantity 
and quality of light reflected from the mulch surface to the leaves, resulting in an increase in nutrient concentrations in the leaves. A similar conclusion was reached by Ashrafzzaman et al. (2011).

Plastic film mulching method is critical for raising farmer revenue and increasing vegetable production. In this regard, the practicality of employing black plastic mulch for early harvesting and increased tomato output is confirmed by our assessment results. For the fresh market, early production is critical because it commands higher pricing. Mulch improved soil-water holding capacity, allowing for greater aeration and drainage, as well as improved root growth and nutrient absorption by agricultural plants (Wan and Kang, 2006). As a result, early yields were possible. Mulch can also manage salinity, allowing the osmotic pressure surrounding the roots of a young plant to be kept low enough to enhance mineral absorption and plant growth. Atallah (2005) and Berihun (2011) came to the same overall result.

Liu et al. (2014) found that grain and cash crop yields have increased by $20-35 \%$ and $20-60 \%$, respectively, due to plastic film mulch technology. Plastic mulching had the biggest effect on potato yield in China, according to Gao et al. (2019). Our findings are further supported by research by El-Wahed et al. (2020) and Pahlevani et al. (2021). Mulching has been shown to reduce water losses through evaporation, hence improving plant growth and development, according to the researchers. This can be linked to a decreased rate of water loss from the soil owing to evaporation and a higher rate of transpiration due to the mulch application, resulting in higher photosynthetic efficiency, which is directly related to crop development.

Many earlier researches (e.g., Dáz-Pérez, 2010; Zhang et al.,2011; Liu et al.,2012) have shown that applying plastic mulch improves soil structure, soil temperature, soil water dynamics, hydraulic conductivity, and water holding capacity, resulting in higher yields of both vegetable and field crops. El-Wahed et al., 2017 found that when no mulching is applied, the soil salinity is higher than when mulching is applied. This could be an additional factor in increasing tomato yield in mulched plots.

It's worth noting that in the presence of plastic mulch, the average vitamin C and TSS content in mulched tomato plants increased significantly. Mulching's beneficial effects on plant growth, nutrient uptake, and soil $\mathrm{CO}_{2}$ levels undoubtedly influenced the physiological processes within tomato fruits, improving their quality. TSS increased, according to Sharma and Agrawal (2004), while V.C concentration in potato tubers increased when $\mathrm{PE}$ film has been put in use, according to Moor et al. (2005). It's also worth noting that the differences seen in our study between the two tomato hybrids could be related to hereditary variants. Following Agrawal et al. (2010) these findings could be explained in light of genetic differences amongst hybrids.

\section{Conclusion}

Black plastic mulch has been proven to produce beneficial environmental conditions for tomato plants by eliminating weed competition, reducing competition with the plant for water and soil resources, which is a key challenge in weed-infested areas. As a result, as compared to the control, the maximum values of tomato output were obtained by utilizing black plastic mulch, but herbicides remained superior to manual weeding practice.

\section{Conflict of interest}

The authors declare that there is no conflict of interest with anyone.

\section{Funding sources}

The research work was performed by individual funding. No financial support was received. 


\section{References}

Abdelsamie, A. E., Hend A. Hamed, Nakagawa, M. (2012). 'Production of main summer crops under irrigation water shortage-A case study of two villages in Egypt.', Annual Meeting of Kyosei Studies, Utsunomia City, Japan, 12/7/2010. Journal of Kyosei studies, Japan, 6 (1), pp. 117-138. https://ci.nii.ac.jp/naid/40019393637/

Agrawal, N., Panigrahi, H.K., Sharma, D., Agrawal, R. (2010). 'Effect of different colour mulches on the growth and yield of tomato under Chhattisgarh region', Indian Journal of Horticulture, 67(4), pp. 295300.

Alyokhin, A., Nault, B., Brown, B. (2020). 'Soil conservation practices for insect pest management in highly disturbed agroecosystems-a review', Entomologia Experimentalis et Applicata, 168(1), pp.727.

A.O.A.C. (2016). 'Official Methods of Analysis', 16th Edition, Association of Official Analytical Chemists, Washington DC.

Ashrafuzzaman, M., Abdul-Halim, M., Ismail, M.R. Shahidullah, S.M., Hossain, M.A. (2011). 'Effect of plastic mulch on growth and yield of chilli (Capsicum annuum L.)', Brazilian Archi'. of Biol. and Technol', 54 (2), pp. 321-330.

Attallah, S.Y. (2005). 'Growth, yield, and its components in some tomato cultivars grown on different dates as affected by soil mulch under Assiut conditions.', Ph.D. Fac.Agric., Assuit Univ., Assuit, Egypt.

Berihun, B. (2011). 'Effect of mulching and amount of water on the yield of tomato under drip irrigation', Journal of Horticulture and Forestry, 3 (7), pp. 200206.

Bhandari, H.R., Srivastava, K., Eswar Reddy, G. (2017). 'Genetic variability, heritability, and genetic advance for yield traits in tomato (Solanum lycopersicum L.)', International Journal of Current Microbiology and Applied Sciences, 6(7), pp. 4131-4138.

Decoteau, D.R. (2008). 'The emergence and early development of colored reflective plastic mulch technology in agriculture', Recent advances in agriculture. Research Signpost. Kerala, India, pp.1-17.

Díaz-Pérez, J.C. (2010). 'Bell pepper (Capsicum annum L.) grown on plastic film mulches: effects on crop microenvironment, physiological attributes, and fruit yield', Hortscience, 45, pp.1196-1204.

Doro, K.O., Ehosioke, S., Aizebeokhai, A.P. (2020). 'Sustainable Soil and Water Resources Management in Nigeria: The Need for a Data-Driven Policy Approach', Sustainability, 12(10), pp. 4204.

El-Wahed, A., Hassan, M., Al-Omran, A.M., Hegazi, M.M., Ali, M.M., Ibrahim, Y.A.M., EL Sabagh, A. (2020). 'Salt distribution and potato response to irrigation regimes under varying mulching materials', Plants, 9(6), pp. 701.

Gao, H., Yan, C., Liu, Q., Ding, W., Chen, B., Li, Z. (2019). 'Effects of plastic mulching and plastic residue on agricultural production: A meta-analysis', Science of the Total Environment, 651, pp. 484-492.

George, E., Rolf, S. John, R. (2013). 'Methods of Soil, Plant, and water analysis: A manual for the West Asia and North Africa region', International Center for Agricultural Research in the Dry Areas (ICARDA), 65, pp,120.

Gomez, K.A., Gomez, A.A. (1984). 'Statistical Procedures for Agricultural Research', 2nd Edn., John Wiley and Sons Inc., New York, USA., pp.13-175.

Hayes, D. G., Anunciado, M. B., DeBruyn, J. M., Bandopadhyay, S., Schaeffer, S., English, M., Sintim, H.Y. (2019). 'Biodegradable plastic mulch films for 
sustainable specialty crop production', In Polymers for Agri-food applications. Springer, Cham, pp. 183-213.

He, L.N., Rogers, R.D., Su, D., Tundo, P., Zhang, Z.C. (2016). 'Green chemistry and sustainable technology', Springer Nature Switzerland AG. Part of Springer Nature, Electronic ISSN 2196-6990.

Hudu, A.I., Futuless, K.N., Gworgwor, N.A. (2002). 'Effect of mulching intensity on the growth and yield of irrigated tomato (Lycopersicon esculentum Mill.) and weed infestation in semi-arid zone of Nigeria', Journal of Sustainable Agriculture, 21(2), pp. 37-45.

Jayan, P.R., Sathyanathan, N. (2012). 'Aquatic weed classification, environmental effects, and the management technologies for its effective control in Kerala, India', International Journal of Agricultural and Biological Engineering, 5(1), pp. 76-91.

Johnson, M.S., Fennimore, S.A. (2005). 'Weed and crop response to colored plastic mulches in strawberry production', HortScience, 40(5), pp. 1371-1375.

Kumar, N., Hazra, K.K., Nadarajan, N. (2016). 'Efficacy of post-emergence application of Imazethapyr in summer mungbean (Vigna radiata L.)', Legume Research-An International Journal, 39(1), pp. 96-100.

Lalitha, M., Thilagam, V.K., Balakrishnan, N., Mansour, M. (2010). 'Effect of plastic mulch on soil properties and crop growthA review', Agricultural Reviews, 31(2), pp. 145-149.

Liu, H., Yang, H., Zheng, J., Jia, D., Wang, J., Li, Y., Huang, G. (2012). 'Irrigation scheduling strategies based on soil matric potential on yield and fruit quality of mulched-drip irrigated chili pepper in Northwest China', Agricultural Water Management. 115, pp. 232-241.
Liu, E.K., He, W.Q., Yan, C.R. (2014). 'White revolution 'to 'white pollution'agricultural plastic film mulch in China', Environmental Research Letters, 9(9), pp. 091001.

Metcalfe, E. (1987). 'Atomic Absorption and Emission Spectrometry', John Wiley\& Sons, New York.

Moor, U., Karp, K., Põldma, P., Pae, A. (2005). 'Cultural systems affect content of anthocyanins and vitamin $\mathrm{C}$ in strawberry fruits', European Journal of Horticultural Science, 70(4), pp. 195.

Nishimura, S., Komada, M., Takebe, M., Yonemura, S., Kato, N. (2012). 'Nitrous oxide evolved from soil covered with plastic mulch film in horticultural field', Biology and fertility of soils, 48(7), pp. 787-795.

Patil Shirish, S., Kelkar Tushar, S., Bhalerao Satish, A. (2013). 'Mulching: A soil and water conservation practice', Research Journal of Agriculture and Forestry Sciences ISSN, 2320, 6063.

Rahman, M.J., Uddin, M.S., Bajum, S.A., Mondol, A.T., Zaman, M.M. (2006). 'Effect of mulches on the growth and yield of tomato in the coastal area of Bangladesh under rainfed' conditions', International Journal of Sustainable Crop production, 1(1), pp. 6-10.

Rajablariani, H., Rafezi, R., Hassankhan, F. (2012). 'Using Colored Plastic Mulches in Tomato (Lycopersicon esculentum L.) production', International Conference on Agriculture and Animal Science, 47(3), pp.12-16.

Rajablariani, H.R., Sheykhmohamady, M., AghaAlikhani, M. (2015). 'Growth of sweet corn and weeds in response to colored plastic mulches', Journal of Advanced Agricultural Technologies, 2(1), pp. 42-45.

Rashidi, M., Gholami, M., Abbassi, S. (2010). 'Effect of plastic mulch and tillage 
method on yield and yield components of tomato (Lycopersicon esculentum)', Journal of Agricultural and Biological Sciences, 5(4), pp. 5-11.

Schwarz, D., Thompson, A.J., Kläring, H.P. (2014). 'Guidelines to use tomato in experiments with a controlled environment', Frontiers in plant science, 5 , pp. 625.

Shamshiri, R.R., Jones, J.W., Thorp, K.R., Ahmad, D., Che Man, H., Taheri, S. (2018). 'Review of optimum temperature, humidity, and vapor pressure deficit for microclimate evaluation and control in greenhouse cultivation of tomato: a review', International agrophysics, 32(2).

Sharma, R., Bhardwaj, S. (2017). 'Effect of mulching on soil and water conservationA review', Agricultural Reviews, 38(4), pp. 311-315.

Shrefler, J., Brandenberger, L. (2014) 'Use of plastic mulch and row covers in vegetable production.', Oklahoma Cooperative Extension Service, HLA-6034, https://hdl.handle.net/11244/50365.2 .

Steinmetz, Z., Wollmann, C., Schaefer, M., Buchmann, C., David, J., Tröger, J., Schaumann, G.E. (2016). 'Plastic mulching in agriculture. Trading shortterm agronomic benefits for long-term soil degradation?', Science of the total environment, 550, pp. 690-705.

Tomar, S., Beniwal, D., Rajiv, S., Kumar, P. (2020) 'Effect of time of planting and mulching on weed intensity in the tomato (Solanum lycopersicum) crop' Indian Journal of Agricultural Sciences, 90(10), pp. 1921-4.

Wan, S., Kang, Y. (2006). 'Effect of drip irrigation frequency on radish (Raphanus sativus L.) growth and water use', Irrigation Sciences, 24, pp. 161-174.

Welbaum, G.E. (2015). 'Vegetable production and practices.', $C A B I$.
Yusak, N.A., Abd Aziz, N.Z., Fahimi, M., Mohame, R. (2016). 'Green Plasticulture', International Journal of Advances in Science Engineering and Technology. 4(2), pp. 41-45.

Zhang, S., Li, P., Yang, X., Wang, Z., Chen, X. (2011). 'Effects of tillage and plastic mulch on soil water, growth and yield of spring-sown maize', Soil Tillage Research, 112, pp. 92-97. 